\title{
(IM)POSSÍVEL EXPERIÊNCIA: LITERATURA E ALTERIDADE, TEORIA CRÍTICA E FICÇÃO CIENTÍFICA
}

\section{Diogo Cesar Nunes}

Resumo: Este artigo tem a intenção de realizar uma abordagem teórica da literatura de ficção científica através da Teoria Crítica da Sociedade, privilegiando o problema da "experiência" no mundo moderno, e perguntando sobre a possibilidade da sua realização mediante a alteridade promovida pelos textos literários.

Palavras-chave: Experiência; Teoria Crítica da Sociedade; Ficção Científica; Alteridade; Literatura Distópica.

Abstract: This article aims to make a theoretical approach of science fiction literature through the Critical Theory of Society, focusing on the problem of "experience" in the modern world, and asking about the possibility of its realization by the otherness stimulated by literary texts.

Keywords: Experience; Critical Theory of Society; Science Fiction; Otherness; Distopian Literature.

Como você se sentiria e o que poderia ocorrer com você naquele mundo estranho, povoado de seres desconhecidos?

H. G. Wells.

\footnotetext{
1 Professor do UNIABEU Centro Universitário e pesquisador do Grupo de Pesquisa "Subjetividade, Narrativas, Imagens" (CNPq/PPGPS-UERJ). Historiador; doutorando em Psicologia Social pela Universidade do Estado do Rio de Janeiro. E-mail: diogodcns@gmail.com.
} 
A Ficção Científica, afirmou Carl Freedman (2000, p. XV), de todos os gêneros atuais, é a literatura que apresenta "a mais profunda e mais interessante afinidade com os rigores do pensamento dialético”. Se Lukács viu no romance histórico um privilegiado gênero para o materialismo dialético, argumenta Freedman, "a Ficção Científica desfruta - e deve ser reconhecida como desfrutando - de tal posição não somente em relação ao marxismo, mas à Teoria Crítica como um todo". Além de apresentarem, enquanto discursos, "afinidades estruturais", "Ficção Científica e Teoria Crítica têm o potencial de desempenhar papéis decisivos na libertação humana da opressão.” (FREEDMAN, 2000, p. XX).

Freedman justifica seu trabalho na convicção de que a aproximação pode completar a ambas, e que a teoria crítica "como uma maneira de ler" evidencia na Ficção Científica, literatura do "estranhamento cognitivo", três elementos "críticos", não obstante comuns: a mutabilidade da história, a preeminência das condições materiais da existência e a possibilidade utópica. Concordando com ele, tomaremos um caminho específico: refletir sobre a importância do "outro", da alteridade, articulada aqui como eixo da relação entre Teoria Crítica e Ficção Científica, enquanto possibilidade de realização da "experiência".

Para tanto, começaremos com uma breve abordagem da noção de experiência como categoria epistemológica, por assim dizer, de acordo com a filosofia de Theodor Adorno. Diferentemente do que este conceito significa na teoria do conhecimento kantiana, referido à intuição sensível, em Walter Benjamin e em Adorno "experiência” tem sentido existencial, uma vez que pressuposta correspondência entre epistemologia e teoria social (e demais especialidades, como a Estética). Adiante, trataremos, de modo amplo e introdutório, alguns temas de destacadas obras ficcionais, entrecortadas por apontamentos de crítica social e literária.

Motivados pela suspeita de que, no interior do mundo administrado, instrumental e unidimensional que dá face à modernidade ocidental - onde a lógica de mercado converte e conforma pensamento e linguagem à sua manutenção e reprodução -, a ficção científica seja capaz de promover estranhamentos, dúvidas e críticas à ordem vigente, tentaremos abordar estas fissuras abertas pela literatura como formas de luta e resistência ao cenário de reificação. A “vida danificada" (ADORNO, 2008) produzida pelo capitalismo ocidental é causa e efeito do esvaziamento da experiência, que implica na fragilização das relações interpessoais, no arquivamento da memória e obstrução da expectativa de futuro que supere o presente, na alienação do tempo, na precarização da linguagem e do pensamento. Aspectos estes que, com efeito, caracterizam "a situação espiritual de nossa época", como escreveu Luiz Bicca (1999, p. 55), de individualismo, alienação e, reciprocamente, melindre e afastamento do outro.

Em Sobre Sujeito e Objeto, Theodor Adorno afirmou que a "experiência" é o "conceitochave" do sujeito no conhecimento (ADORNO, 1995, p. 194). Para compreender esta frase é preciso antes de tudo retirar do sujeito qualquer essência particular. Não há um principium individuationis, elemento "metafisicamente derradeiro ou imutável", que faça do ser humano um sujeito dotado de uma identidade individual, per se (2009, p. 185). A ideia de um "puro em si absoluto" é uma "ilusão", pois “o sujeito que é pretensamente em si é mediado nele mesmo por aquilo do que ele se separa: a conexão com todos os sujeitos" (2009, p. 181).

Note-se que Adorno não propõe um conceito de sujeito, como o que Stuart Hall (2006, p. 30) chamou de "sociológico", fundado na "interação" entre o Eu e o mundo. O sujeito é 
mediado "nele mesmo". Ou seja, o mundo "exterior", chame-se de realidade objetiva, sociedade, contexto e/ou simplesmente meio, não é propriamente externo, mas elemento constitutivo do "interior". "Nele mesmo", mas "separado": o sujeito é duplo. "Interno" e "externo" não são elementos antitéticos, ou opostos, paralelos que por ventura se encontrem e cruzem, mas dialéticos: um só existe por causa do outro; e, mais, um existe "no" outro.

O sujeito, portanto, não é "constituinte". Nem princípio metafísico, em si e para si, nem fonte última de significação do mundo. Entretanto, e aqui há uma das muitas distinções possíveis de serem traçadas entre o pensamento adorniano e o de Michel Foucault, ele também não é unicamente "constituído" exteriormente pelas relações de saber-poder. Ao compreender "sujeito" não somente como elemento epistemológico abstrato, mas como aquele que "determina" a ação, capaz de, lembrando Kant (1974), fazer uso do seu próprio entendimento, e de, como propôs Ernst Bloch (2000, p. 3), tomar a existência em suas próprias mãos, a Teoria Crítica, diferentemente do Foucault da genealogia do poder, pensará o sujeito como "possibilidade": não como resultado de um processo de "assujeitamento" ou interiorização do exterior. Ainda que o mundo moderno crie diversas "tecnologias" e “dispositivos" de "disciplinarização", “docilização", conformação e individualização, e certamente o faz, a realização do sujeito se mantém como possibilidade que se renova a cada instante. Pois, como afirmou Bloch (2005, Vol. III p. 12),

Não há sequer um entre todos nós que não possa ser também outro. Um arbusto, em princípio, contenta-se com o fato de ser arbusto. Todavia um ser humano pode tornar-se, por assim dizer, tudo, inacabado como é, escuro e indefinido como é em si mesmo.

Neste sentido, se há algo que se aproxime de uma essência no humano é o fato de ser indefinido, inacabado: poder "ser outro". Também Foucault, em seus últimos livros e aulas, apontou para esta questão, ao dizer que se mobilizava não por "descobrir o que somos, mas recusar o que somos [...,] imaginar e construir o que poderíamos ser", promovendo "novas formas de subjetividade" através da recusa da individualidade que "nos foi imposta há vários séculos.” (FOUCAULT, 1995, p. 239). Contudo, por descartar a dialética e por não incorporar a intersubjetividade, afirma Sergio Paulo Rouanet (1987, p. 187-188), a proposta foucaultiana da constituição do sujeito "livre", que tenha poder sobre si, presente sobretudo nos dois últimos volumes da História da Sexualidade, é a de um sujeito em relação monológica consigo mesmo, num "processo de individualização integral”. Se Foucault abandonou (ou supôs abandonar) a "filosofia do sujeito" por considerá-la também aporética, ou seja, por se sustentar numa categoria (sujeito) que é ao mesmo tempo transcendental e empírica, para a Teoria Crítica não há impasse nessa duplicidade, pelo contrário. Pois, como argumenta Rouanet, "essa aporia só é inevitável na perspectiva monológica [...]. Esse dilema desaparece quando a intersubjetividade assume o primeiro plano" (1987, p. 185). Ainda que a "intersubjetividade" se evidencie na Teoria Crítica em Habermas, e não em Adorno, cabe atentar que, para este, "se fosse possível especular sobre a reconciliação", seria unicamente em termos de uma "comunicação do diferenciado" (ADORNO, 1995, p. 184). Não obstante, trata-se de operar a "superação" do sujeito, e não 
sua liquidação, pois isto significaria "não somente a regressão da consciência, mas sim a recaída em uma real barbárie".

O que mantém a validade do sujeito é justamente a sua duplicidade, seja em se tratando do transcendente, seja em se tratando do empírico (como também a relação entre $a^{m b o s}{ }^{2}$ ). Pois, se em termos epistemológicos sujeito e o seu aparente "outro", o objeto, se interpenetram, também assim, o "homem vivo", o "indivíduo vivente”, se mantém como sujeito em potência por conta do seu caráter inacabado: ele pode superar-se, ser "outro". Este, todavia, embora não seja presente realizado, é presente enquanto possibilidade, o que significa que, uma vez que sua existência seja processo inconcluso (ou seja, devir), ele "é" também o seu "não-ser". Se a subjetividade se faz de passado, não somente o lembrado, mas o escondido da memória ordinária, também se faz de potencialidades adormecidas, que o indivíduo, na sua constituição indeterminada de ser "sujeito", buscará despertar.

Que a "experiência" seja o "conceito-chave" da constituição do sujeito significa que este se realiza no encontro com o outro - no mundo "exterior" e/ou no "interior". Etimologicamente, tanto em alemão (Erfahrung, do verbo Fahren) quanto em latim (através do radical Per), experiência refere-se a: busca, procura, erro, risco, dar-se com o perigo, navegação pelo desconhecido, viagem em direção ao novo (Cf. MATOS, 2007). Experiência é, portanto, "experiência da alteridade", saída do já-sabido, do conhecido, do lugar de conforto para ter com o não-idêntico, o não-eu, o dessemelhante. Na Teoria do Conhecimento, aponta para o que Adorno (1995, p. 187-188) chamou de "primazia do objeto", que é a "intentio obliqua da intentio obliqua e não requentada intentio reta". Explicando: um mecanismo que não pretende eliminar a subjetividade e resgatar "a servil confiança no ser-assim do mundo exterior", mas "corrigir" a "redução subjetiva” operada pela teoria tradicional, que, ao dar primazia ao sujeito, o reduz ao "vazio" e representa, não obstante, um movimento "ideológico", de reificação em vez de superação. O sujeito como fonte primeira e última de significação do mundo está completamente alienado dele, incapaz de criticá-lo, transformá-lo e transformar, assim, a si mesmo.

"Teoria do conhecimento é teoria social”, afirma Adorno, por isso a atenção à epistemologia e, também por isso, esta atenção não se encerra nela - sujeito não é somente um "universal". A experiência (da alteridade, portanto) permite conhecer o outro externo, mas também (e por isso) reconhecer o próprio lugar, parcial, impreciso e precário, do Eu. Como diz o antropólogo François Laplantine (1994, p. 21), "presos a uma só cultura, somos não apenas cegos às dos outros, mas míopes quando se trata da nossa". Pensar aqui em termos de cultura em vez de individualidade é fundamental: "nele mesmo", o indivíduo assim se constitui pelo que lhe precede, atravessa e ultrapassa. Como disse Walter Benjamin (1989, p. 107), “onde há experiência no sentido estrito do termo entram em conjunção a memória, certos conteúdos do passado individual com outros do passado coletivo".

\footnotetext{
2 Adorno rejeita tanto a abordagem que trata o sujeito somente como transcendental quanto a que o individualiza, ou seja, que o trata como algo essencialmente "fora" do mundo social, deslocado do seu contexto, a-histórico e "ensimesmado": o sujeito em-si-mesmo. A dialética do conceito de sujeito, em Adorno, aponta que se não se pode falar de sujeito enquanto instância lógica sem individualidade, também a individualidade, tomada assim como um "universal", se insere no transcendente.
} 
Como o sujeito, a experiência não é dada, não é natural. Trata-se de um exercício cujo resultado é o incerto, pois é, a rigor, o exercício do erro, ou melhor, da errância. Entretanto, no mundo moderno, a realização da experiência encontra barreira não somente na "ideologia" do sujeito em-si, mas também na mercantilização cada vez mais total das atividades humanas - na conversão em elementos de exploração e reificação daquilo que, potencialmente, se aliariam à emancipação do homem. Escreveu Benjamin (1994, p. 46): "as rugas e as dobras do rosto são as inscrições deixadas pelas grandes paixões, pelos vícios, pelas intuições que nos falaram, sem que nada percebêssemos, porque nós, os proprietários, não estávamos em casa”. E não estávamos em casa porque o tempo, que seria um aliado da experiência, seu motor, converteu-se em coisa - e nos persegue, nos alienando dele e de nós, então seus servos. Porque, dominados pelo tempo-coisa e pela instrumentalização do mundo, estamos mais próximos da condição de mercadorias que da de "sujeitos", incapazes que somos, plasmados num eterno presente, de projetar nossa superação em devir. E porque, sobretudo, preferimos escapar do risco, do erro, do confronto conosco mesmos e do encontro com o desconhecido em favor, em termos gerais, do "princípio da identidade", que restringe o próprio sujeito enquanto potência. O homem moderno se coloca no mundo assim como um turista que nem precisa de bússola, pois, de mapa em riste, "visita" os pontos-turísticos programados pela agência, mediado sempre pelo guia que explica em sua língua o que "é” cada coisa que seus olhos veem.

O mundo se apresenta, assim, aos nossos "olhos" como pronto, dotado de uma lógica em-si de não-contradição, mediados - e, podemos dizer, con-formados - que somos pelos aparatos ideológicos. Cabe ao pensamento crítico, antes de qualquer coisa, romper com a totalidade estanque do mundo, quebrando, fragmentando, fracionando o que vem já-pronto e, no mais das vezes, com manual de uso. Trata-se, como escreveu Adorno (2008, p. 245), de "construir perspectivas em que o mundo se ponha, alheado, com suas fissuras e fendas à mostra". E aqui se situa a importância da arte: não para projetar imagens positivadas da realidade, mas, pelo contrário, negando-a de dentro, evidenciar suas fissuras - criando buracos, projetando sombras, construindo perspectivas outras em que o permanente, o nãocontraditório e harmônico deem lugar ao conflito, à vertigem, ao não-idêntico. Enfim, que “a não-identidade [seja] o telos da identificação". (MATOS, 1998, p. 110).

Ao positivar a realidade, a arte tão somente contribui para que as coisas permaneçam como estão, ou seja, retroalimentando a exploração e a alienação, engessando o mundo e o indivíduo, livrando-o do outro. A literatura, em específico, e a arte, em geral, ao converterem-se em produtos industriais, de mercado, em "entretenimento", e abrirem mão do confronto, do contraditório, e do seu caráter formador - pois se trata na indústria cultural de promover uma "semi-formação", fornecendo ao "consumidor" um eterno retorno ao jásabido e ao esperado - atuam contra as possibilidades de realização da experiência e da "superação". Como afirmou Paul Ricouer, "a ficção só tem virtude de manifestar algo na medida em que possibilita uma força transformadora” (RICOUER, 1999, p. 229) - e a transformação, lembramos Harold Bloom (2000, p. 17), "tem caráter universal”.

São nestes sentido e contexto que a Ficção Científica nos aparece como um campo da literatura capaz de contrariar, se não o mercado como um todo - o que seria ingenuidade -, a reificadora tendência da arte positiva de naturalizar a vida, forjar a totalidade da re- 
alidade e eliminar os conflitos da existência por meio da negligência da alteridade. Sem querer dizer, em absoluto, que "toda" literatura deste gênero o faça, muito menos que seja ela a "única” a fazê-lo, a Ficção Científica, afirmou J. C. Ballard, "explora as ambiguidades do mundo".

Para prosseguir, atentemos a um trecho da introdução de Crash, que, embora longo, é bastante significativo:

Vivemos num mundo governado por ficções de toda espécie. O merchandising de massa, a publicidade, a política conduzida como um ramo da propaganda, a tradução instantânea da ciência e da tecnologia em imagens populares, a crescente mistura e interpenetração de identidades no reino dos bens de consumo, de apropriação pela televisão de qualquer resposta imaginativa livre ou original à experiência. Nossa vida é uma grande novela. Para o escritor, em particular, torna-se cada vez menos necessário inventar o conteúdo ficcional de sua obra. A ficção já está aí. A tarefa do escritor é inventar a realidade. No passado, sempre consideramos que o mundo exterior em torno de nós representava a realidade, por mais incerta ou confusa que fosse, e que o mundo interior de nossas mentes, seus sonhos, esperanças e ambições, representava o reino da fantasia e da imaginação. Esses papéis, também, me parecem, foram invertidos. O mais prudente e efetivo método de lidar com o mundo ao nosso redor é assumir que ele é uma ficção completa, e, inversamente, que o único e pequeno núcleo de realidade que nos resta está no interior das nossas próprias cabeças. A clássica distinção de Freud entre conteúdos manifesto e latente do sonho, entre o aparente e o real, precisa agora ser aplicada ao mundo externo da assim chamada realidade. (BALLARD, 2007, p. 8).

O mundo em que vivemos é uma grande ficção. Que outro nome dar à realidade absolutamente dominada por "fantasmagorias", pelo enfeitiçamento das "coisas" materiais e pela coisificação do humano, e que se nos apresenta como totalidade dada, já-pronta! Se a ideologia converteu-se em realidade e a ciência em ideologia; se a tecnologia é quem determina, controla, dita a vida do homem, e as possibilidades de experiência foram usurpadas pela indústria cultural, esta realidade é uma não-realidade. A inversão conceitual proposta é a recusa da assimilação integral ao estado de coisas, à objetivação total do humano, brecha que se abre para a negação do existente: cabe à imaginação crítica "inventar a realidade". Não obstante, este "salto para fora" da negação tanto visa quanto é guiado pela "primazia do objeto", ou seja, por uma análise objetiva mundo. Ballard não negligencia que, para usar suas próprias palavras, "o mundo interior da mente e o mundo exterior da realidade encontram-se”. Ao contrário, é justamente por serem interpenetrados que o pensamento - resquício do "real", lugar onde se pode conservar um mundo não corrompido -, pode (e, no caso, deve) invadir o mundo objetivo, abalando sua ordem e suposta estabilidade. A análise é objetiva, e por sê-la é que se permite pensar, projetar, "inventar" o contrário, "o outro lado".

Ainda que não possa ser abalizado, em sentido stricto, como Ficção Científica, o conto Micrômegas, de Voltaire, pôs em cena de forma paradigmática o encontro com o outro. 
Publicado em 1752, ele narra a aventura de um habitante da estrela Sirius, que, após problemas com as autoridades locais, decide viajar pelo universo, até chegar ao sistema solar. Ao passar por Saturno, fez amizade com o Secretário da Academia do planeta, a quem Voltaire se refere como "anão", tendo o acolhido como companheiro de jornada. E eis que Micrômegas e o anão chegam à Terra, um pequenino planeta que, de tão miúdo, sequer lhes parece propriamente um planeta - pisavam numa poça, que batia no meio da perna do anão e mal molhava o salto do sapato do outro, esta que chamamos Mar Mediterrâneo. Após duvidarem que pudesse haver vida naquele lugar, e de terem dado volta inteira no globo em 36 horas, lhes ocorre que talvez seus habitantes sejam demasiado pequenos aos seus olhos, e põem-se a tatear em busca de nativos.

Micrômegas estendeu a mão com toda delicadeza na direção em que o objeto apareceu, aproximou dois dedos, e logo os retirou por receio de cometer um desacerto; depois abriu e fechou-os, tomando muito cuidadosamente a embarcação que transportava esses senhores [destacados filósofos em expedição], e também a colocou sob a unha sem apertá-la muito, temendo esmaga-la. (VOLTAIRE, 2007, p. 47).

A insignificância física da Terra e dos filósofos, sua pífia presença fronte ao universo, inverte a perspectiva da razão soberana, tão preciosa no século XVIII. É Micrômegas, o gigante universal, quem olha com piedade a pequenez humana, e julga o que pode sua razão, representada pelos distintos senhores do saber que habitam a embarcação, “átomos pensantes", e o que lhes contavam da Terra. "Horríveis querelas entre animais tão medíocres": a violência do homem sobre o homem, ser que trabalha para sua própria ruína, vizinha, contudo, de admiráveis proezas, destacada inteligência e demonstrada criatividade - como uma raça tão pequena vive em tantos contrastes?

Aos homens, aquele viajou todo o universo e o conhece com propriedade pode avaliar e julgar. Admirável a razão humana, mas terrível sua tendência de servir à destruição. A ironia de Voltaire se lança ainda a duas outras críticas: fronte ao gigante interessa aos filósofos humanos poder conhecer e afirmar as "verdades universais", e a resposta de Micrômegas à questão da verdade universal, o fim de todas as coisas, não é menos desconcertante que o próprio encontro projetado.

[...] por desgraça, havia ali um animalículo de capelo que cortou a palavra a todos os animalículos filosofantes: disse que sabia o segredo de tudo, o qual se achava na Suma de Santo Tomás; mediu de alto a baixo os dois habitantes celestes; sustentou-lhes que as suas pessoas, os seus mundos, sois e estrelas, tudo era feito unicamente para o homem. A isto, os nossos dois viajantes tombaram um nos braços do outro, sufocados de riso, esse riso inextinguível que, segundo Homero, é próprio dos deuses; seus ombros e ventres agitavam-se e, nessas convulsões, o navio que Micrômegas trazia na unha caiu no bolso das calças do saturniano. Os dois o procuraram por muito tempo; afinal encontraram e reajustaram tudo convenientemente. $\mathrm{O}$ siriano retomou os pequenos insetos; falou-lhes de novo com muita bondade, embora no íntimo se achasse um tanto agastado de ver que os 
infinitamente pequenos tivessem um orgulho quase infinitamente grande. Prometeu-lhes que redigiria um belo livro de filosofia, escrito bem miudinho, para seu uso, e que, nesse livro, veriam eles o fim de todas as coisas. Com efeito, entregou-lhes esse volume, que foi levado para a Academia de Ciências de Paris. Mas, quando o secretário o abriu, viu apenas um livro em branco. - Ah! bem que eu desconfiava... - disse ele. (VOLTAIRE, 2007, p. 58).

O "olhar" do outro, "de fora", permite evidenciar os contrastes. O universo inteiro feio para o Homem - este que se apequena por completo na imensidão do universo. A verdade universal na ponta da caneta dos filósofos - estes que se perdem no bolso do gigante. "Infinitamente pequenos, com orgulho infinitamente grande". O fim de todas as coisas cabe perfeitamente num livro: com páginas em branco.

Na definição paradigmática de Darko Suvin (1979), a ficção científica é a literatura do "estranhamento cognitivo". Ao criar um Novum, um mundo-outro, desloca as referências do que é real, causando o chamado "efeito estranhamento". Embora não sejam os únicos, o futuro e a presença de seres extraterrestes são os elementos mais recorrentes, na história da ficção científica, com os quais se articula o distanciamento da realidade fática, forja a alteridade e possibilita o estranhamento. Se a relação entre os mundos "interior" e "exterior" pressupõe recíproca interpenetração, e, portanto, mobilidade e transformação, de modo análogo se pode pensar o problema da temporalidade, tão caro à ficção científica. Topos onde se passa maioria das tramas científico-ficcionais, o futuro se coloca como parte essencial de uma estratégia narrativa que reflete sobre o presente. Como afirmou Freedman (2000):

[...] De todos os gêneros, a Ficção Científica é ainda o mais devotado à concretude histórica e à rigorosa auto-reflexão da Teoria Crítica. Seu mundo não é simplesmente um lugar no tempo e no espaço diferente do nosso, mas que quer evidenciar justamente a diferença, que se realiza como continuum do atual - o que a distingue gravemente dos estranhamentos irracionais da fantasia e da literatura gótica [...].

Uma vez que consequência do presente, o futuro está nele, dialeticamente inserido. Ao marcar o "lugar" da diferença, o futuro se apresenta no tex to não estritamente enquanto artifício narrativo, qual se analisaria de modo puramente formal, mas espaço aberto para pensar a mutabilidade da história e, talvez servindo de "aviso", de "despertador" sobre o futuro que se está construindo no agora (MOYLAN; BACCOLINI, 2003), negar os fatalismos conformistas que se congelam na "presentificação" do tempo. Trata-se da crítica do tempo presente. Mas, ao fazê-la através do outro, permite um ver-se de fora renovador e revelador, que, em vez de identificar o não-idêntico e familiarizar o desconhecido, preserva o quanto pode a integridade do outro, e, assim, sua potência contestatória.

A Ficção Científica se inscreve, assim, numa dialética do tempo, mas alocada no interior do discurso científico, tomando dele seus símbolos e signos - por isso se revela tão especial para esta reflexão. Ela se desdobra para dentro da própria dinâmica da cientificidade 
- esta que, ao menos desde Frankenstein, de Mary Shelley, e de movimentos operários quebra-máquinas dos oitocentos, desperta atenção também por conta dos perigos que faz provocar. Diferente da literatura fantástica, a ficção científica guia-se pela "não impossibilidade" da realização empírica do que projeta - sustentada, por um lado, na progressiva presença da ciência (e, claro, das suas extensões tecnológicas) na vida cotidiana hodierna, e, por outro, na suspeita/certeza de que o desenvolvimento científico-tecnológico não tem limites. Por isso, ao buscar inserir-se dentro da lógica científica, realizando um "efeito metalinguístico" (BERNARDO, 2010, p. 245), desdobra-se no tempo: para o futuro. Se a vida e a sociedade se mostram cada vez mais tecnologizadas e cientificizadas, e os "progressos" da ciência e da tecnologia parecem não ter limites, cabe perguntar, o que faz a ficção científica, como será o futuro. Ela levanta, diz Bernardo, "graves suspeitas sobre os fins e os meios da ciência, desconfiando que a ampliação do poder da espécie humana graças à ciência suporia a redução, inversamente proporcional, do poder e da liberdade de cada ser humano".

O breve conto O Pedestre, de Ray Bradbury, põe em cena de maneira direta, porém sutil, esta relação entre tecnologia e liberdade. No ano de 2053, cem anos exatos da escrita do texto, Leonard Mead é preso e levado ao "Centro Psiquiátrico de Pesquisa em Tendências Regressivas" por ter sido pego caminhando pelas ruas depois das oito horas da noite. Ao ser interpelado pela polícia:

\footnotetext{
"Ocupação ou profissão?"

"Acho que poderiam me chamar de escritor".

"Sem profissão", disse o carro de polícia, como um espécime em um museu, alfinete traspassado no peito.

"Pode-se dizer que sim", disse o sr. Mead. Ele não escrevia fazia muitos anos. Revistas e livros não tinham mais muita saída. Todas as coisas seguiam seu rumo nas casas sepulcrais, agora à noite, ele pensou, prosseguindo em sua fantasia.

Os sepulcros mal iluminados pela luz dos televisores onde as pessoas se sentavam, como os mortos, com as luzes cinza ou multicoloridas tocando seus rostos, mas nunca realmente as tocando. (BRADBURY, 2008, p. 163).
}

O caminhar é o exercício próprio da "errância", o que vale nos sentidos metafórico, literal, e no encontro de ambos que alguns textos conseguem realizar. É contra o perigo do erro, e, portanto, da experiência, que o mundo futuro escrito por Jerome K. Jerome (1981), em The New Utopia de 1891, é estruturado urbanisticamente em ruas largas, lineares e retas. Não obstante, não há sujeitos neste mundo: o Estado pensa pelos indivíduos, provendo -os de tudo - seguindo caminhos sempre retos, não passam de reproduções intermináveis do mesmo. No caso de Mead, caminhar a esmo, sem maiores expectativas que o próprio ato, significa fugir da instrumentalização da vida, do utilitarismo e da apatia provocada pela "luz dos televisores". O caminhar que não visa finalidade outra que não seja si mesmo, põe em relevo o caráter incerto da existência em devir, motivo de angustia e terror por parte da razão instrumental. "Como mortos", os habitantes do futuro de Bradbury se reúnem todas as noites em frente à televisão, num mundo em que "livros não tinham mais muita saída”. 
A tecnologia, representada em Bradbury pelos televisores, invade a vida cotidiana isolando os indivíduos uns dos outros, fragilizando as relações sociais e transformando um caminhar despropositado numa patologia "regressiva". Os meios de comunicação, que supostamente aproximariam as pessoas, acabam afastando-as - das outras pessoas, do mundo e de si próprias -, tornando-se eles, os aparatos tecnológicos, os protagonistas da existência, e os seres humanos, seus apêndices, num constante "exercício de fuga, de velamento sobre si mesmos" (SOARES; EWALD, 2004, p. 6), cada vez mais vazios e, paradoxalmente, ensimesmados. Não obstante, o enfraquecimento da literatura não é fenômeno secundário, mas fundamentalmente preso numa relação causal com o empobrecimento da experiência. No mesmo ano de $O$ Pedestre foi publicado o famoso romance Fahrenheit 451 (BRADBURY, 2012), em que temas presentes em vários contos e novelas de Bradbury, como o supracitado, são explorados, com destaque a relação que a sociedade estabelece com a literatura. Neste mundo futuro, os livros são proibidos - os encontrados, queimados a $451^{\circ}$ fahrenheit; seus donos, perseguidos e, se preciso, asilados em hospícios.

A política deliberadamente iconoclasta é suportada e animada pela primazia cultural da indústria do entretenimento, com a qual a decadência da literatura marca posição bem definida, carregando consigo a capacidade de construção de perspectivas outras, críticas, que contrastem com a realidade objetiva. A política do entretenimento, como aponta Luiz Bicca (2003, p. 12), disfarça a heteronomia e as contradições da condição humana, aliandose a um niilismo formador de caráter "interesseiro, ansioso e facilmente instrumentalizável [...], tão propenso a recorrer a uma violência terrível sempre que os próximos ou vizinhos não se adaptam às suas crenças”.

Não é acaso, pois, que "literatura" e "liberdade" se encontrem etimologicamente na raiz latina liber (Cf. VATTIMO, 2000). Não se trata de um encontro formal, relegado ao baú exótico da erudição gramatical e histórica, mas de uma relação que situa e é situada nos entrecruzamentos da luta humana pelo humano. O arquivamento da literatura, seu empobrecimento e conversão em produto mercadológico, correspondem ao definhamento da pergunta pela liberdade. Neste sentido, o diagnóstico sugerido pelo controverso Regras para um Parque Humano, de Peter Sloterdijk, é inquietante e temeroso. O fracasso (do projeto) da cultura baseada na literatura é o fracasso do sonho da humanização do homem, restando o embrutecimento e "a bestialização cotidiana das pessoas pelos entretenimentos desinibidores da mídia”. (SLOTERDIJK, 2000, p. 17). Não há, pois, motivos para duvidar do caráter antecipatório das ficções científicas que prognosticaram um mundo em que o controle genético pré-natal se impõe sem qualquer pudor e praticamente sem resistências. Derrotado o projeto humanista, a barbárie se coloca desobstruindo a mediação que a "cultura" supunha (tentar) desenvolver no processo de "domesticação" do humano. Pergunta Todorov (2008, p. 9): "Depois da morte de Deus e do desmoronamento das utopias, sobre qual base intelectual e moral queremos construir nossa vida comum?". O problema urgente não seria a dificuldade de se articular uma resposta precisa à inquietante pergunta, mas a constatação de que a questão levantada corresponde a este projeto de "cultura" formadora, cada vez mais debilitado, fragilizado, provavelmente vencido; ou seja, que a própria pergunta pelo destino dos homens se esvazie de sentido, reduzida ao campo genético, e, no limite, se ausente. 
Promovendo uma "antropologia do inumano" - o humano extremo-outro, desfigurado -, do pós-humano, enfim, a experiência do encontro com o "fracasso do humano", como argumenta João Camilo Penna (2008), a Fiç̧ão Científica pode(ria) animar a identificação com o não idêntico, de modo que o destino comum dos homens (e o próprio sentido de "humanidade", baseado na empatia) se põe como problema. Os riscos e perigos do embrutecimento do homem, do empobrecimento da experiência e da "tecnoligização" da vida subjetiva, social e orgânica - se revelam a partir de uma estrutura (ou estratégia) narrativa que "convida" o leitor a "experienciar" os conflitos e angústias do protagonista lançado ao mundo-outro. Com o personagem em perigo se pode estabelecer empatia, num misto de identidade e diferença, com a qual a aparente mesmidade do Eu possa ser questionada e abalada, permitindo abertura à alteridade (Cf. RICOUER, 1999).

Admirável Mundo Novo, de Aldous Huxley (2008), põe em cena estas questões supracitadas, centradas na redução do humano, promovida pelo biopoder, à condição de homo economicus. No Mundo Novo, os "humanos" são produzidos em série, ao modelo fordista, em fábricas chamadas Laboratórios, tendo seu processo total de adaptação à sociedade tocado por um complexo sistema de "condicionamento" que tem início antes mesmo de nascer e se estende durante toda vida. A "civilização", como Huxley denomina, é finalmente baseada integralmente na razão instrumental e cartesiana: não há espaços para o sensível, tampouco para o erro, o equívoco, o desvio ao "destino social" ao qual os indivíduos são programados e con-formados.

O "efeito estranhamento" é provocado mediante alguns elementos-chave da narrativa, dentre eles o próprio nome "civilização": dado ao mundo totalmente controlado pela ciência e por aquela razão. Os "bárbaros" vivem numa ilha distante, a "reserva selvagem”, onde há “o tempo, a morte, e Deus" (HUXLEY, 2008, p. 165), estes elementos do "humano do passado" que só fazem provocar angústia e mal viver. O homem finalmente civilizado e feliz haverá de viver num mundo sem literatura, sem beleza, sem arte, sem família ou quaisquer laços afetivos que possam ir além da efêmera utilidade, reduzidas que são as relações sociais, outrossim a própria vida individual, à pura instrumentalidade.

Outro elemento fundamental da narrativa que produz "estranhamentos" é a sorte do protagonista, através da qual a realidade objetiva se revela opressiva e hostil. No livro de Huxley, Bernard Marx e John, o selvagem, guiam com seus destinos tortuosos a construção da trama, privilegiando o estranhamento que o dualismo, então paradoxal, civilização-barbárie permite lançar. Através dos olhos inseguros de Bernard, o leitor conhece o Mundo Novo, e eles revelam um universo patético de atos, gestos e pensamentos que reproduzem, como alto-falantes do sistema, as frases e os mandamentos "aprendidos", como que por Diktat, de um complexo sistema educacional que acompanha os personagens desde a gestação. O ano 632 d. F. (depois de Ford), tão distante e tão próximo, tanto dos anos 1930 da sua escrita quanto dos atuais, vê realizado em diversos aspectos a racionalização total da sociedade, aliada a um modo de produção em massa que não se limita ao universo do trabalho: pelo contrário, padroniza toda a vida da sociedade. "Comunidade, Identidade, Estabilidade", o "lema planetário" (HUXLEY, 2008, p. 14) do Estado. “[...] homens são de espírito obedientes, satisfeitos em sua estabilidade. [...]. Estabilidade. A necessidade fundamental e definitiva" (p. 55-56). 
Bernard, ao contrário, é instável. E Huxley não se priva de evidenciar seus conflitos e misérias: é também invejoso e rancoroso. Como que buscando uma pitié inversa, espécie de empatia ao fracasso, faz do seu primeiro protagonista um inumano que se aproxima do leitor lembrando-o justamente de predicados que, à luz da razão e da moral retas, talvez preferisse esconder. Em contato com a Reserva Selvagem, Huxley opera a "troca” de protagonistas: John (o selvagem), aspirante a herói, toma lugar na trama. John sim reúne qualidades que permitem uma aproximação "simpática" com o leitor, contemporâneo de Huxely ou nosso - fronte ao civilizado Mundo Novo, os selvagens transitam contemporaneamente entre as bárbaras décadas do breve século XX, ao menos ainda até agora, o que dota a obra de uma pertinência histórica interessante, talvez crônica. No entanto, John não é um típico selvagem: destacado leitor de Shakespeare, refinado e moralista, é um sem-lugar entre os seus, que unicamente são "seus" à luz da nova civilização.

Levado ao Mundo Novo, John, o outro do outro, é lançado mundo hostil da alteridade radical; sua saga, metáfora (deliberada) do conflito entre a moral monogâmica judaicocristã aliada à "(alta) cultura" da tradição ocidental e a racionalidade técnica ligada a um projeto de erotização corpórea. Tomar parte dele é menos conflitivo que de Bernard: John ama sua mãe, ensaia um romance passional com a personagem Lenina; sua raiva, justificada, mas a todo instante ironizada pelo narrador: John, o humano, o selvagem. Digno de repugnância, piadas, desprezo.

Os seguidos tumultos e rebeliões protagonizados pelo selvagem o levam a conhecer o Administrador Mundial Residente para a Europa Ocidental, aquele que faz as leis, e, portanto, pode transgredi-las:

- Por vezes mil instrumentos melodiosos sussurram em meus ouvidos, e, por vezes, vozes. ${ }^{3}$

A fisionomia do Selvagem iluminou-se em súbito prazer.

- O senhor também o leu? Julguei que ninguém tivesse ouvido falar nesse livro aqui na Inglaterra. [...] Mas por que ele está proibido? - perguntou o Selvagem. Na excitação de conhecer um homem que havia lido Shakespeare, esquecera momentaneamente de tudo o mais.

$[\ldots]$

- Porque é antigo; essa a razão principal. Aqui não queremos saber de coisas antigas.

- Mesmo quando são belas?

- Sobretudo quando são belas. A beleza atrai, e nós não queremos que ninguém seja atraído por coisas antigas. Queremos que amem as novas. (HUXLEU, 2008, p. 265).

O irracional da racionalidade tem propósitos objetivos: a tão deseja Estabilidade é também conquistada mediante novidades efêmeras. Ânsia pela novidade, que, na fetichização

\footnotetext{
3 "Sometimes a thousand twangling instrumenst / Will hum about my ears, and sometimes voices". Shakespeare. A Tempestade, III, 2.
} 
das mercadorias e do consumo, con-forma o indivíduo consumido pelo que supostamente consome, obliquando a própria possibilidade do individualizar-se senão pela reificação. "Mais vale dar fim que consertar. Quanto mais se remenda menos se aproveita" (HUXLEY, 2008, p. 53), máxima da civilização do efêmero. Dialética da Estabilidade, conquistada através do instável que destrói em si o seu oposto. John, o alienígena, no Mundo Novo da perfeição só faz aprofundar e agravar a imperfeição que marca sua humanidade: o sofrimento. Seu fim é o fim da trama; fim dos seus conflitos e dilemas. Atravessado de culpa, raiva e dor, dá cabo de sua imperfeição:

A porta do farol estava entreaberta. Empurraram-na e entraram numa penumbra de janelas fechadas. Por um arco na outra extremidade do local viam-se os primeiros degraus da escada que levava aos andares superiores. Exatamente sob o fecho do arco pendiam dois pés.

- Sr. Selvagem!

Lentamente, muito lentamente, como duas agulhas de bússola sem pressa, os pés voltaram-se para a direita: norte, nordeste, leste, sudeste, sul, sul-doeste; depois se detiveram e, passados alguns segundos, recomeçaram a girar, com a mesma lentidão, para a esquerda. Sul-doeste, sul, sudeste, leste... (HUXLEY, 2008, 313-314).

Mediante a sutil relação entre mesmidade e diferença, identificação com o protagonista fracassado, empatia ao outro em risco (Cf. PENNA, 2008), e, assim, possibilidade de experiência, a alteridade projetada pela ficção científica seria capaz de desnaturalizar a realidade objetiva, revelada enquanto histórica: não mais palco estático sobre o qual caem os indivíduos, mas resultado incerto das suas ações incertas. Se "Narciso acha feio o que não é espelho", como diz a canção de Caetano Veloso (1978), pintar um quadro desfigurado do Eu aparente ativaria novas formas de subjetivação que escapem à reificação, implicando na necessária superação das imagens congeladas do Ego e do mundo social, então não mais alienadas - entre si, e, portanto, em si. O olhar de estranhamento, no instante de perigo e testemunha do fracasso, negando a pacificação e a regressão à imobilidade identitária, abriria fresta de escape à realidade totalizante, na qual outra coletividade, talvez ainda impensada, mas não impossível, possa ser lançada como superação do presente.

\section{REFERÊNCIAS BIBLIOGRÁFICAS}

ADORNO, Theodor W. Dialética Negativa. Rio de Janeiro: Zahar, 2009.

. Minima Moralia. Reflexões a partir da vida lesada. Rio de Janeiro: Azougue, 2008.

. Palavras e Sinais. Modelos críticos 2. Petrópolis: Vozes, 1995. 
BALLARD, James Graham. Crash. São Paulo: Cia. das Letras, 2007.

BENJAMIN, Walter. Obras Escolhidas I. Magia e Técnica, Arte e Política. São Paulo: Brasiliense, 1994. . Obras Escolhidas III. Baudelaire - um lírico no auge do capitalismo. São Paulo: Brasiliense, 1989.

BERNARDO, Gustavo. O Livro da Metaficção. Rio de Janeiro: Tinta Negra, 2010.

BICCA, Luiz. O Mesmo e os Outros. Rio de Janeiro: 7 Letras, 1999.

. Questões Persistentes. Rio de Janeiro: 7 Letras, 2003.

BLOCH, Ernst. O Princípio Esperança. Vol. III. Rio de Janeiro: Ed. UERJ, 2005.

The Spirit of Utopia. California: Stanford University Press, 2000.

BLOOM, Harold. Como e Por que Ler. Rio de Janeiro: Objetiva, 2000.

BRADBURY, Ray. Fahrenheit 451. São Paulo: Ed. Globo, 2012.

O Pedestre. In: A Cidade Inteira Dorme e Outros Contos Breves. São Paulo: Ed. Globo, 2008.

FOUCAULT, Michel. O Sujeito e o Poder. In: DREYFUS, H.; RABINOV, P. Michel Foucault: uma trajetória filosófica. Rio de Janeiro: Forense Universitária, 1995.

FREEDMAN, Carl. Critical Theory and Science Fiction. Middletown: Wesleyan University Press, 2000.

HALL, Stuart. Identidade Cultural na Pós-Modernidade. Rio de Janeiro: DP\&A, 2006.

HUXLEY, Aldous. Admirável Mundo Novo. São Paulo: Globo, 2008.

JEROME, Jerome Klapka. The New Utopia. In: Diary of a Pilgrimage. New York: Henry Holt and Co., 1981.

KANT, Imanuel. Resposta à Pergunta: o que é Esclarecimento? In: Textos Seletos. Petrópolis: Vozes, 1974.

LAPLANTINE, François. Aprender Antropologia. São Paulo: Ed. Brasiliense, 1994.

MATOS, Olgária. “Tempo sem Experiência”. Documentário Invenção do Cotidiano. Série: Experiências no tempo, curadoria: Olgaria Matos. São Paulo: CPFL Cultura, 2007. 1 DVD, Fullscreen, son., color.

Vestígios: escritos de filosofia e crítica social. São Paulo: Palas Athena, 1998. 
MOYLAN, Tom; BACCOLINI, Raffaella. Dystopia and Histories. In: Dark Horizons: science fiction and the dystopian imagination. New York; London: Routledge, 2003.

PENNA, J. C. Máquinas Utópicas e Distópicas. In: NOVAES, Adauto. Mutações. Rio de Janeiro: Agir. 2008.

RICOEUR, Paul. Historia y Narratividad. Barcelona: Paidós, 1999.

ROUANET, Sérgio Paulo. As Razões do Iluminismo. São Paulo: Cia. das Letras, 1987.

SOARES, Jorge Coelho; Ewald, Ariane P. "Reflexões à sombra de Adorno". Nomadas, n. especial, 2004. Disponível em: http://www.existencialismo.uerj.br/pdf/Nomadas.pdf

SUVIN, Darko. Metamorphoses of Science Fiction. New Haven; London: Yale University Press, 1979.

SLOTERDIJK, Peter. Regras para um Parque Humano. São Paulo: Estação Liberdade, 2000.

VATTIMO, Gianni. “Livro - Liberdade”. Revista Tempo Brasileiro, vol. 142, 2000.

VELOSO, Caetano. Sampa. In: Muito Dentro da Estrela Azulada. PolyGram do Brasil, 1978, faixa 7.

VOLTAIRE, François Marie. Micrômegas. In: Micrômegas e Outros Contos. São Paulo: Hedra, 2007. 